\title{
Study of Oxytocin Receptor in Human Myometrium Using Highly Specific ${ }^{3}$ H-Labeled Oxytocin
}

\author{
Hideki SAKAMOTO, Konbai DEN, Koichi YAMAMOTO, \\ TAKENORI ARAI, SHUN KAWAI, YoICHI OYAMA, \\ TAKAO YOSHIDA AND SHIGEO TAKAGI \\ Department of Obstetrics and Gynecology, Nihon University School \\ of Medicine, 30-1 Oyaguchi-Kamimachi, Itabashi-Ku, Tokyo Japan
}

\begin{abstract}
Synopsis
A highly specific tritium labeled oxytocin $\left({ }^{3} \mathrm{H}-\mathrm{OT}\right)$ was synthesized utilizing the method of catalytic substitution of halogen for hydrogen. The specific activity of ${ }^{3} \mathrm{H}$-OT was $19 \mathrm{Ci} / \mathrm{mM}$ and the biologic activity was $350 \mathrm{U} / \mathrm{mg}$, which was sufficient for the OT radioreceptor assay. The maximum \% uptake of ${ }^{3} \mathrm{H}-\mathrm{OT}$ in the human

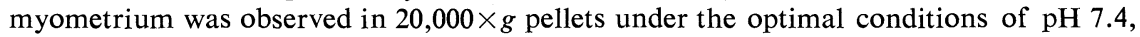
at $20^{\circ} \mathrm{C}$ and the incubation time of $90 \mathrm{~min}$ and it was augmented in the presence of $\mathrm{Mn}^{++}$. It was also observed from the Scatchard plot, that the binding site of OT in the human myometrial specimens was a single type within the range of OT concentration of $0.4 \mathrm{nM}$ to $1.6 \mathrm{nM}$. The dissociation constants $(\mathrm{Kd})$ and the number of binding sites (NBS) showed a relative increase as gestation advance. The apparent $\mathrm{Kd}$ of term pregnancies was $1.25 \times 10^{-9} \mathrm{M}$ regardless of the presence or absence of labor pains, while the NBS of term pregnancies with and without labor pain was $1.2 \times 10^{-12}$ and $4.7 \times 10^{-12}$ moles $/ \mathrm{mg}$ protein, respectively.
\end{abstract}

It is well known that the uterine myometrial contractions are induced by the administration of oxytocin (OT) which is thought to play the main role in controlling the onset of labor, namely parturition. We know of no reports concerning the mechanism of the action of OT in the uterus during parturition, even though there have been some studies on plasma OT levels (Chard et al., 1971; Kumaresan et al., 1974; Dawood et al., 1977) and on the specific binding site for ${ }^{3} \mathrm{H}-\mathrm{OT}$ in the uterus (Soloff et al., 1974). One of the reasons for such a small number of reports is the lack of isotopically labeled OT with a high specific activity as well as high biologic activity. Therefore, we attempted to synthesize a ${ }^{3} \mathrm{H}$-labeled OT by the method of catalytic substitution of di-iodo OT for tri-

Received January 17, 1979. tiated OT according to the modified methods of Agishi and Dingman (1965) and Morgat et al (1970). Using this newly synthesized ${ }^{3} \mathrm{H}-\mathrm{OT}$ with a specific activity of $19 \mathrm{Ci} / \mathrm{mm}$ and with biologic activity of $350 \mathrm{U} / \mathrm{mg}$, several investigations were made on human myometrial specimens including term pregnancies with and without labor pain in an attempt to clarify the pregnancy related dynamics of OT receptors.

\section{Materials and Methods}

\section{Reagents and Apparatus}

Standard OT (Sanabo, Austria) was stored in $1 \mathrm{mM}$ sodium acetate buffer, $\mathrm{pH}$ 4.6. Ion exchange resin AGII-A8 (50-100 mesh) and Biogel $\mathrm{P}_{2}$ (400 mesh, Bio-Rad Lab.) were used for the column chromatography (CC). Cellulose thin layer chromatography plates (Art 5728, TLC) were obtained from E. Merck A. G., Darmstadt. $5 \% \mathrm{Pd} / \mathrm{CaCO}_{3}$ was from Japan Engelhard and all reagents from Wako Pharmaceuti- 
cal Co. were of analytical grade. $1 \mathrm{mM}$ of phosphate buffer, $\mathrm{pH}$ 6.4, Tyrode's solution, $\mathrm{pH} 7.6$ and $50 \mathrm{mM}$ Tris-maleate buffer, pH 7.4 were prepared. Scintillation fluid was made by dissolving $275 \mathrm{~g}$ of POPOP, $6 \mathrm{~g}$ of DPO and $100 \mathrm{~g}$ of naphthalene in $1,000 \mathrm{ml}$ of dioxane. All glass or teflon potter homogenizer, liquid scintillation spectrometer (Mark III 6880, Searle Analytical Inc.), autowell gamma counter (Aloka JDC 771), thin layer chromatogram scanner (Aloka TLC-2B) and ultraviolet spectrometer (Type 323, Hitachi) were used.

\section{Purification of Standard Oxytocin}

Purification of the standard OT was developed on cellulose TLC, using a solvent system of n-butanol : acetic acid: water $(75: 10: 25)$ and the fractions of which $\mathrm{Rf}$ values were from 0.57 to 0.71 were collected and extracted with $1 \mathrm{~mm}$ phosphate buffer. The extract was then passed through a glass filter (G4) and a millipore ( $1 \mu$ mesh, Amicon Corp.). The purified OT showed $470 \mathrm{U} / \mathrm{mg}$ of biologic activity and was subjected to the following experiment.

\section{Preparation of ${ }^{3} \mathrm{H}$-labeled Oxytocin}

${ }^{3} \mathrm{H}$-labeled OT was synthesized by the modified method of Glover et al. (1967) and Morgat et al. (1970). Standard OT was dissolved in $1 \mathrm{~mm}$ of phosphate buffer and $0.1 \mathrm{M} \mathrm{IC1}$ in methanol was titrated in over a period of $10 \mathrm{~min}$ at $4^{\circ} \mathrm{C}$. After adding $0.1 \mathrm{M}$ sodium thiosulfate, the mixture was transferred to the ion exchange resin $\mathrm{CC}(8 \times 50 \mathrm{~mm})$ to remove the inorganic salts. The di-iodinated OT fraction was further submitted to Biogel $P_{2} C C(20 \times 400 \mathrm{~mm})$ using $1 \mathrm{mM}$ phosphate buffer as an effluent with the flow rate of $0.2 \mathrm{ml} / \mathrm{min}$. The protein concentration of the fraction, $2.8 \mathrm{ml}$ each, was determined by the Folin method (Lowry et al., 1951) as well as UV spectrum. $1 \mathrm{~g}$ of ion exchange resin was added to the obtained fraction and the mixture was stirred vigorously. The supernatant of the mixture obtained by centrifugation at 3,000 rpm was condensed in vacuo and frozen with liquid nitrogen in a ${ }^{3} \mathbf{H}$ reaction vessel (Hata et al., 1977) after $5 \% \mathrm{Pd} / \mathrm{CaCO}_{3}$ was added as catalyst. The excess ${ }^{3} \mathrm{H}$ gas was perfused in vacuo and the reactant was stirred for $40 \mathrm{~min}$ at $24^{\circ} \mathrm{C}$ with a gas pressure of $250 \mathrm{mmHg}$. The reactant was passed through a millipore and the radiochemical purity was tested until the radioactivity of the product became constant. The crude ${ }^{3} \mathrm{H}-\mathrm{OT}$ was further developed on Biogel $\mathrm{P}_{2} \mathrm{CC}$ with $1 \mathrm{~mm}$ acetate buffer and the protein concentration as well as the radioactivity of each $2.8 \mathrm{~m} l$ fraction was determined.

\section{Preparation of the Uterine Particulate Fraction}

Uterine tissues were obtained from normally menstruating women who had undergone hysterectomy because of myomas or other benign gynecologic problems. First trimester uterine tissues were ob- tained from the surgical cases requiring hysterectomy which were complicated by pregnancy. Term myometria were obtained during the elective or definitive cesarean section from the anterior portion of the lower segment. The specimens were immediately placed in an ice-chest and the subsequent procedures were all carried out at $4^{\circ} \mathrm{C}$. After removing the endometrium, serosal layer and myomatous tissue, the myometrial specimens were minced and homogenized in 5 vol of Tyrode's solution in a potter homogenizer. The homogenate was initially centrifuged at $1,000 \times g$ for $15 \mathrm{~min}$, then the supernatant was further centrifuged at $20,000 \times g$ for $15 \mathrm{~min}$, followed by centrifugation at $105,000 \times g$ for $15 \mathrm{~min}$. All particulate fractions and the final $105,000 \times g$ supernatant were used in the radioreceptor assay. The $20,000 \times g$ pellets were treated according to the method reported by Soloff et al. (1974). The specimens were centrifuged at $20,000 \times g$ for $15 \mathrm{~min}$ and the pellets were washed with 2 vol of Tris-maleate buffer containing $5 \mathrm{mM}$ of $\mathrm{MnCl}_{2}$ and $0.1 \%$ of gelatin. After recentrifugation at $20,000 \times g$ for $15 \mathrm{~min}$, the pellets were suspended in $2 \mathrm{vol}$ of Tris-maleate buffer to give a protein concentration ranging between 1.5 $\mathrm{mg} / \mathrm{m} l$ to $4.0 \mathrm{mg} / \mathrm{ml}$. The incubation was performed as follows; $100 \mu l$ of the specimen, $7,000 \mathrm{dpm}$ of ${ }^{3} \mathrm{H}-\mathrm{OT}$ and sufficient standard OT to make a total volume of $500 \mu l$ of Tris-maleate buffer were incubated at $20^{\circ} \mathrm{C}$ for $90 \mathrm{~min}$ and the reaction was terminated by centrifugation at $20,000 \times g$ for $15 \mathrm{~min}$ at $4^{\circ} \mathrm{C}$. The radioactivity of the pellets dissolved in $200 \mu l$ of $1 \mathrm{~N} \mathrm{NaOH}$ as well as that of the supernatant were both determined simultaneously. Scatchard analysis (Scatchard., 1949) was employed for the determination of apparent dissociation constants $(\mathrm{Kd})$ and the number of binding sites (NBS).

\section{Results}

Commercial grade OT developed on cellulose TLC showed three spots with $\mathrm{Rf}$ values of $0.39,0.48$ and 0.64 the last of which showed a UV spectrum of $275 \mathrm{~nm}$ $(\lambda \max )$ at $\mathrm{pH} 4.6$ and a biologic activity of $407 \mathrm{U} / \mathrm{mg}$ by the avian depressor method. After the Biogel $\mathrm{P}_{2} \mathrm{CC}$, the protein concentration of each $2.8 \mathrm{~m} l$ fraction of di-iodinated OT was determined. The shift of spectrum was observed in fractions 31 to 35 , which showed maximal protein concentrations. The shift was from $275 \mathrm{~nm}(\lambda \max )$ at $\mathrm{pH}$ 4.6 to $312 \mathrm{~nm}(\lambda \max )$ at $\mathrm{pH} 7.0$ (Fig. 1). In another experiment, it was recognized 
that the specific activity of ${ }^{125}$ I-labeled OT was $3.6 \mathrm{Ci} / \mathrm{M}$ which was twice as high as that of ${ }^{125} \mathrm{ICl}, 1.8 \mathrm{Ci} / \mathrm{M}$. And the $\mathrm{Rf}$ value of di-iodinated OT developed on TLC was 0.82 while that of the standard OT was 0.68. The $\mathrm{Rf}$ value of the crude ${ }^{3} \mathrm{H}-\mathrm{OT}$ developed on TLC was almost equal to that of the standard. Adjacent spots, however, were found on TLC that could not be eliminated by the repeated TLC procedure, therefore, further purification was carried out on Biogel $\mathrm{P}_{2} \mathrm{CC}$, the fractions of whose

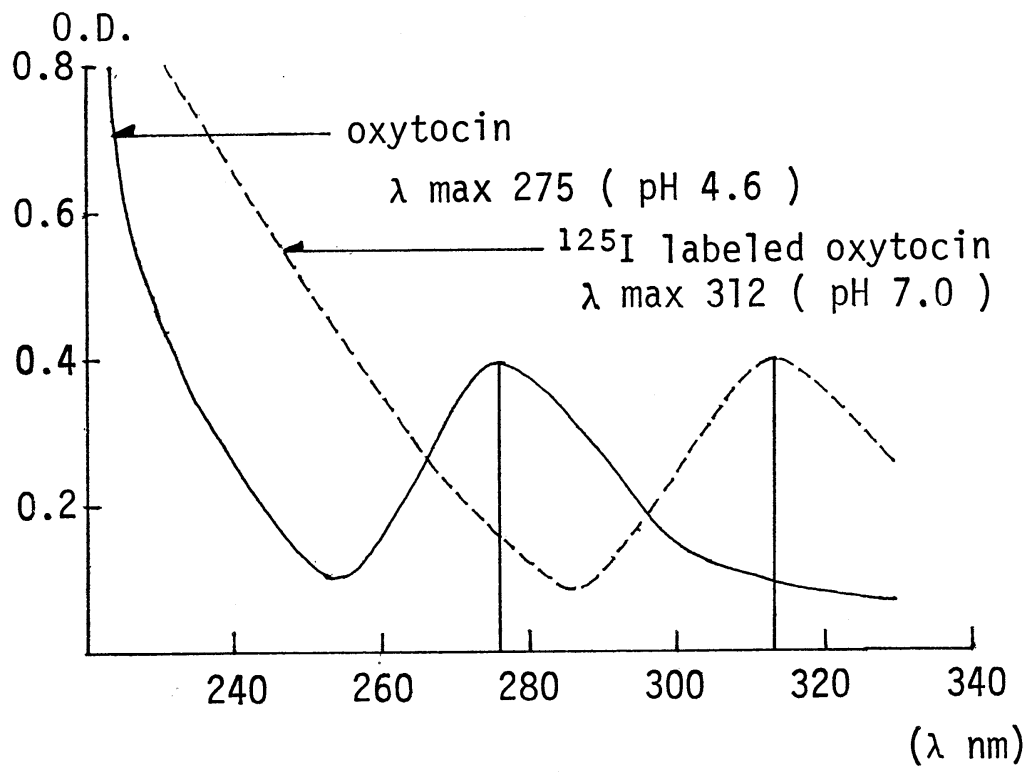

Fig. 1. Ultraviolet spectra of oxytocin and di-iodo oxytocin. The shift of spectra was observed from $275 \mathrm{~nm}(\lambda \max )$ at $\mathrm{pH} 4.6$ to $312 \mathrm{~nm}(\lambda \max )$ at $\mathrm{pH} 7.0$.
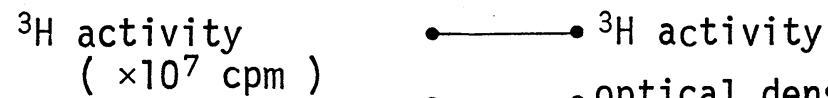
o-n---ooptical density

O.D

$(500 \mathrm{~nm})$

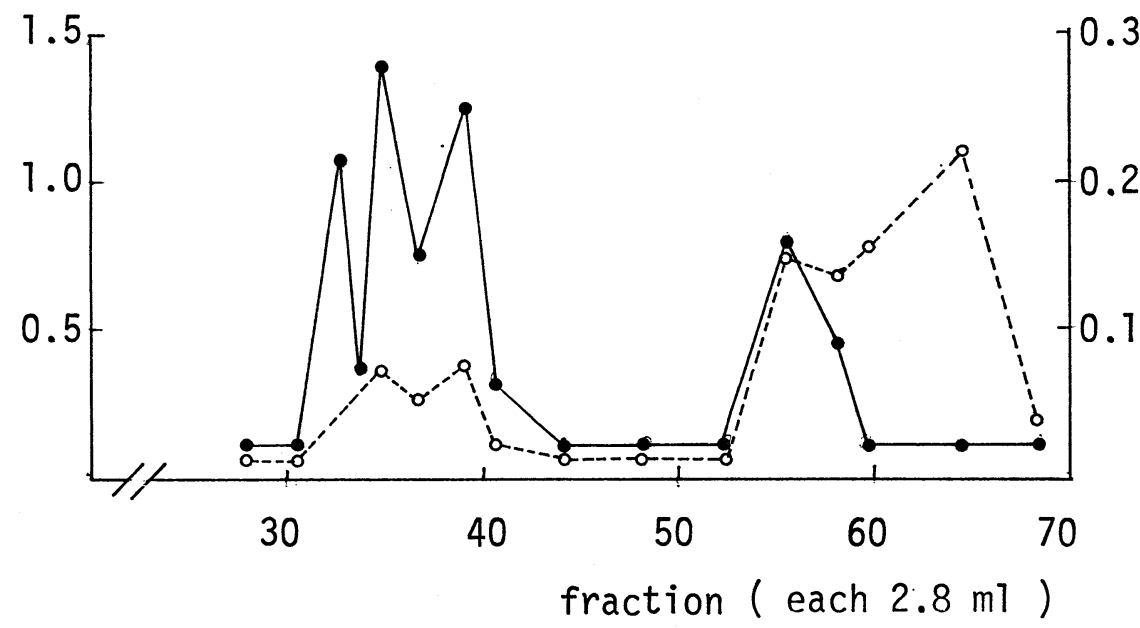

Fig. 2. Elution pattern of ${ }^{3} \mathrm{H}$-labeled oxytocin from a Biogel $\mathrm{P}_{2}$ column chromatography $(20 \times 400 \mathrm{~mm})$ using $10^{-3} \mathrm{M}$ acetate buffer, $\mathrm{pH} 4.6$ as elution buffer. The protein concentration and radioactivity of each $2.8 \mathrm{~m} l$ fraction were determined. 
${ }^{3} \mathrm{H}$ activity corresponded to the optical density were collected (Fig. 2). These fractions were further developed on TLC and Biogel $\mathrm{P}_{2} \mathrm{CC}$ (Fig. 3). It was proved that ${ }^{3} \mathrm{H}-\mathrm{OT}$ finally obtained was $3.8 \%$ and had $19 \mathrm{Ci} / \mathrm{mM}$ of specific activity and $350 \mathrm{U} /$ $\mathrm{mg}$ of biologic activity. This synthesized ${ }^{3} \mathrm{H}-\mathrm{OT}$ was kept at $-70^{\circ} \mathrm{C}$ dissolved in 1 $\mathrm{mM}$ acetate buffer.

In order to determine the optimal conditions for the OT radioreceptor assay, the
$\%$ uptake of ${ }^{3} \mathrm{H}-\mathrm{OT}$ was firstly estimated in $1,000 \times g, \quad 20,000 \times g$ and $105,000 \times g$ pellets as well as in $1,000 \times g, 20,000 \times g$ and $105,000 \times g$ supernatant of the nonpregnant myometrial specimens under varying $\mathrm{pH}$, temperature and the incubation time. The maximum uptake of $7,000 \mathrm{dpm}$ ${ }^{3} \mathrm{H}-\mathrm{OT}$ was observed in the $20,000 \times g$ pellets at about $80 \%$ bound $/ \mathrm{mg}$ protein under the incubation conditions of $\mathrm{pH} 7.4$, at $20^{\circ} \mathrm{C}$ for $90 \mathrm{~min}$ in the volumes of Tris-maleate

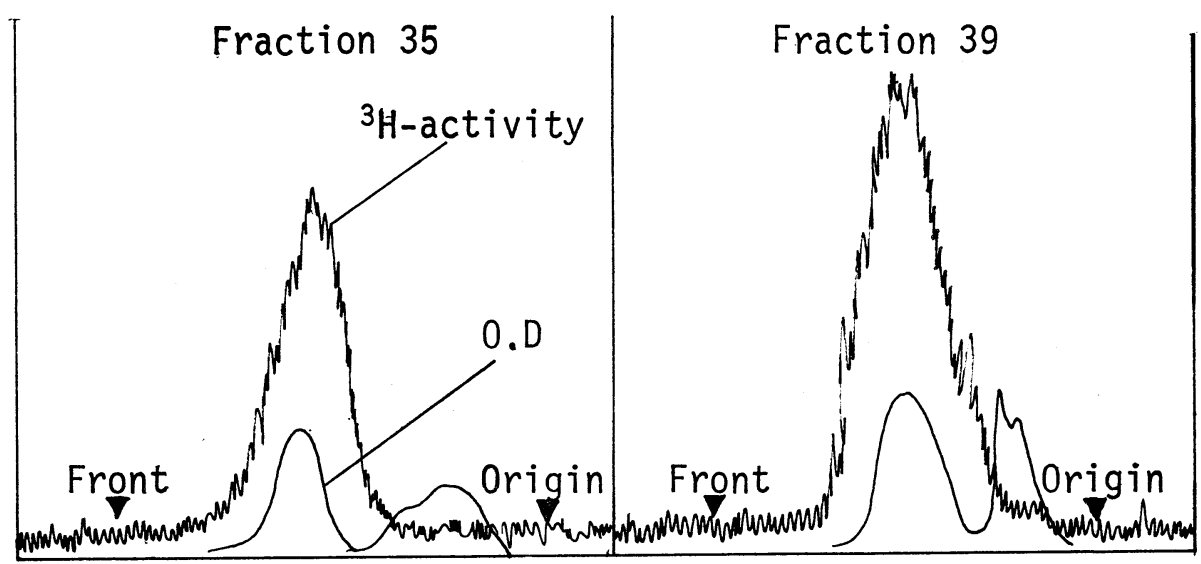

Fig. 3. Identification of ${ }^{3} \mathrm{H}$-oxytocin from cellulose thin layer chromatography using solvent system, n-BtOH : $\mathrm{CH}_{3} \mathrm{COOH}: \mathrm{H}_{2} \mathrm{O}(75: 10: 25)$.

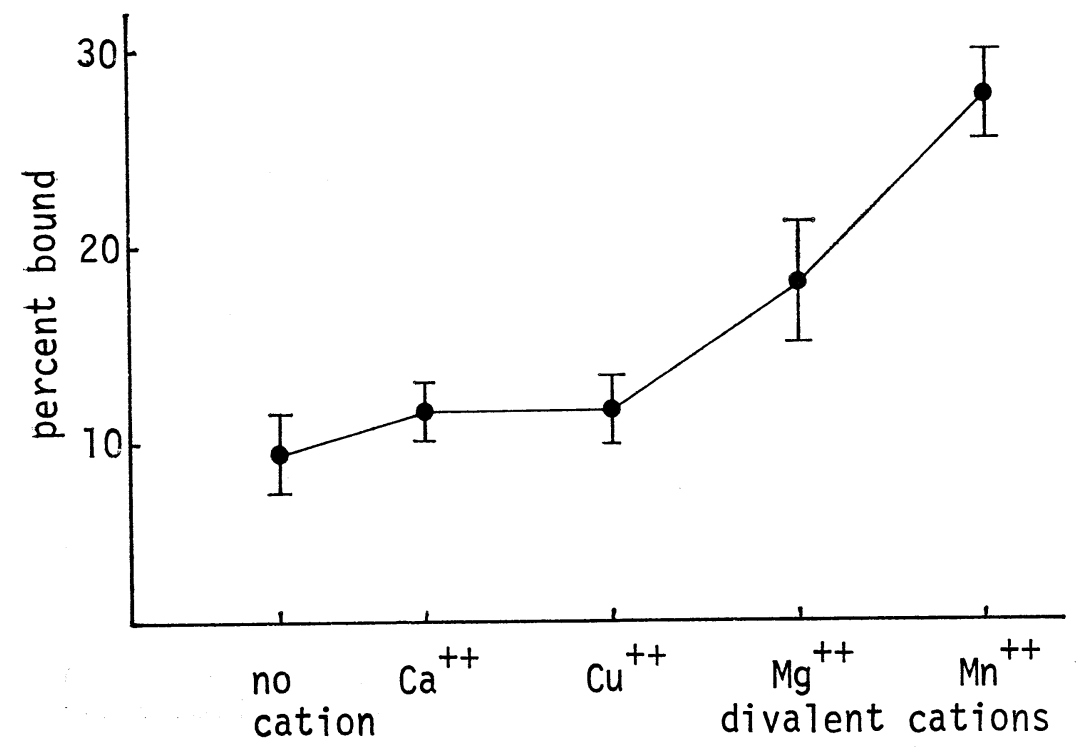

Fig. 5. Effects of various divalent cations on ${ }^{3} \mathrm{H}$ oxytocin binding to the $20,000 \times g$ pellets of human nonpregnant myometrium. Tris-maleate buffer with $5 \mathrm{mM}$ of $\mathrm{Ca}^{++}, \mathrm{Cu}^{++}, \mathrm{Mg}^{++}$and $\mathrm{Mn}^{++}$were prepared and incubation was performed. 

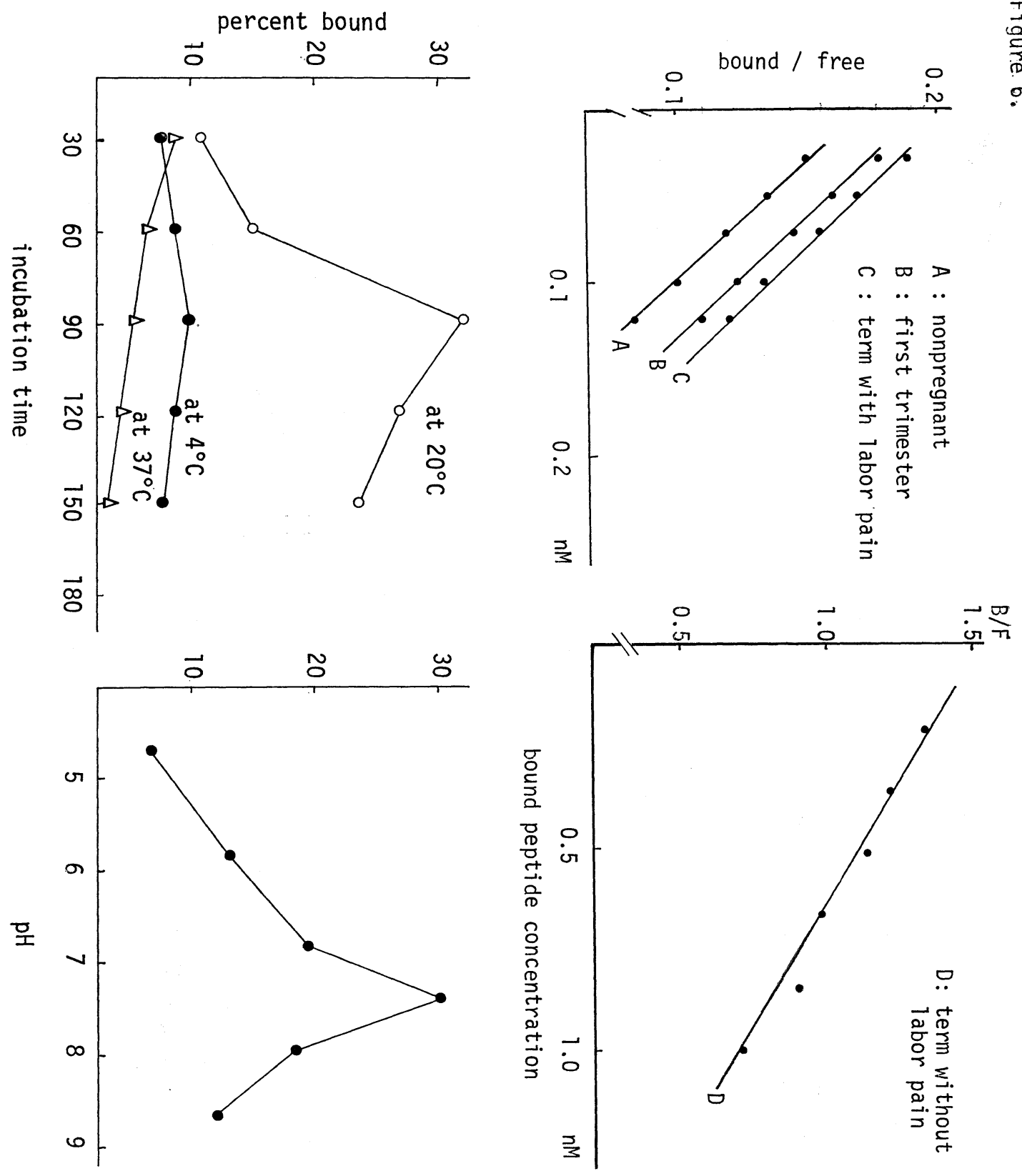

Fig. 4. Effects of incubation time, temperature and $\mathrm{pH}$ on ${ }^{3} \mathrm{H}$-oxytocin binding to the $20,000 \times \mathrm{g}$ pellets of human nonpregnant myometrium. $100 \mu l$ of specimen was incubated with $7,000 \mathrm{dpm}$ of ${ }^{3} \mathrm{H}$-oxytocin to a total volume of $500 \mu \mathrm{l}$ of Trismaleate buffer with various incubation times, tem-

Fig. 6. Competitive radioreceptor assay was performed in the $20,000 \times g$ pellets of nonpregnant, first trimester, term pregnancies with labor pain and without labor pain. The apparent $\mathrm{Kds}$ and the NBS were estimated from Scatchard analysis. perature and $\mathrm{pH}$. 


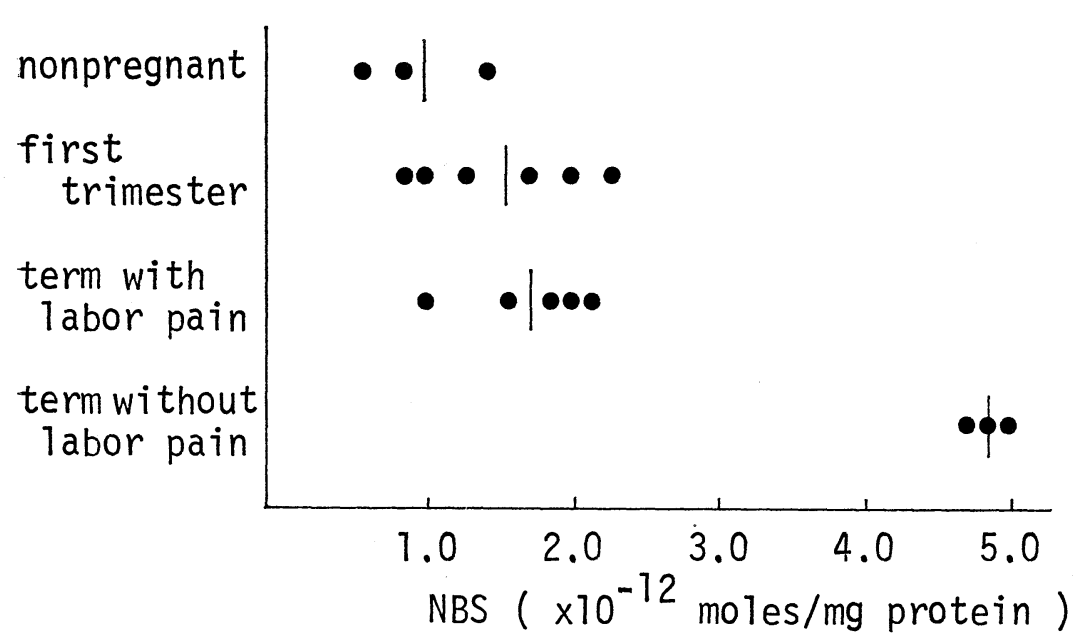

Fig. 7. Comparison of the NBS during gestation and at term by X-intersept of the Scatchard plot.

buffer as shown in the Fig. 4. The \% uptake increased about $40 \%$ in the presence of $\mathrm{Mn}^{++}$and $10 \%$ with $\mathrm{Mg}^{++}$, while no potentiation was observed in the presence of $\mathrm{Ca}^{++}$or $\mathrm{Cu}^{++}$(Fig. 5). The \% uptake to the $20,000 \times g$ pellets was determined and compared in nonpregnancy, first trimester pregnancies and term pregnancies with and without labor pains and the values were $12 \%, 14 \%, 16 \%$ and $30 \%$, respectively. The results of the competitive radioreceptor assay were analyzed by the Scatchard plot, which gave a linear figure with the range of total OT concentrations of $0.4 \mathrm{nM}$ to $1.6 \mathrm{nM}$. The apparent $\mathrm{Kds}$ of the nonpregnant and the first trimester specimens were $1.66 \times 10^{-8} \mathrm{M}$ and $1.64 \times 10^{-8} \mathrm{M}$, and those at term were $1.25 \times 10^{-8} \mathrm{M}$ regardless of the presence or absence of labor pains (Fig. 6). Also the binding capacities of each specimen expressed as NBS were estimated by the X-Intersept of the Scatchard plot. The NBS of the nonpregnant was $1.0 \times 10^{-12}$ moles $/ \mathrm{mg}$ protein, that of the first trimester was $1.1 \times 10^{-12}$ and those of term with labor pain was $1.6 \times 10^{-12}$ while that without labor pain was $4.7 \times 10^{-12}$ (Fig. 7).

\section{Discussion}

Radio-iodinated OT has been widely accepted for RIA because of its high specific activity. It is unsuitable, however, for the radioreceptor assay because of the inactivation of biologic activity and the degradation as a result of the iodination of the tyrosyl ring (Thompson et al., 1973). Thus, it would seem reasonable that the ${ }^{3} \mathrm{H}-\mathrm{OT}$ rather than radio-iodinated OT is preferable for the OT radioreceptor assay. At present, however, ${ }^{3} \mathrm{H}-\mathrm{OT}$ with high specific activity sufficient for the radioreceptor assay is not commercially available, even though Morgat et al (1970) had succeeded in synthesizing a ${ }^{3} \mathrm{H}-\mathrm{OT}$ with a specific activity of $36 \mathrm{Ci} / \mathrm{mM}$ and biologic activity of 300 $\mathrm{U} / \mathrm{mg}$. We attempted to synthesize a ${ }^{3} \mathrm{H}$ OT according to the method of catalytic substitution of di-iodinated tyrosyl ring for ${ }^{3} \mathrm{H}$, using the modified method of Agishi and Dingman (1965) and Morgat et al. (1970) and succeeded in synthesizing a ${ }^{3} \mathrm{H}-\mathrm{OT}$ with a specific activity of $19 \mathrm{Ci} / \mathrm{mM}$ and biologic activity of $350 \mathrm{U} / \mathrm{mg}$ which is sufficient for the radioreceptor assay. There are several points that should be taken into consideration in this experiment, i.e. the purity of 
the standard OT and the procedual losses of biologic activity as well as degradation. The relatively low purity and the biologic activity of the standard OT required further purification on cellulose TLC which appeared to decrease the losses in biologic activity of OT, predicted when other methods were employed. And we have obtained an OT of $25 \%$ purity with biologic activity of $407 \mathrm{U} / \mathrm{mg}$. It is known that the stability of OT is retained in acidic solutions while iodinated $\mathrm{OT}$ tends to lose the $\mathrm{I}_{2}$ from the tyrosyl ring when the $\mathrm{pH}$ is below 5.0. Therefore the reaction step up to the tritiation was carried out in $1 \mathrm{mM}$ phosphate buffer $\mathrm{pH} 6.4$ and thereafter in acetate buffer $\mathrm{pH} 4.6$ to prevent or decrease the degradation of OT. In this study, di-iodination was done applying the method of Glover et al. (1967) and $\mathrm{ICl}$ used was made by dissolving $2 \mathrm{M} \mathrm{KI}$ and $\mathrm{KIO}_{3}$ in concentrated $\mathrm{HCl}$. Identification of the reactants as di-iodo OT is based on the following observations; The UV spectrum shifted to $312 \mathrm{~nm}(\lambda \max )$ at $\mathrm{pH} 7.0$, this agrees with the observation that the peptide containing the iodinated tyrosyl ring shows the specific spectrum shift (Nunez et al., 1962) and the UV spectrum of tyrosine, mono-iodo tyrosine and di-iodo tyrosine are 275,305 and $312 \mathrm{~nm}(\lambda \max )$ at $\mathrm{pH}$ 7.0. Secondly the specific activity of ${ }^{125}$ I-OT was twice as high as that of ${ }^{125} \mathrm{ICl}$ and Rf value of the former on TLC was discriminated from that of the standard OT. Using this di-iodo OT, we carefully performed the catalytic substitution. First, unbound iodine was removed as possible before the catalytic substitution of halogen for hydrogen, because it might inactivate the catalyst. H-I or ${ }^{3} \mathrm{H}-\mathrm{I}$ resulting from the residual iodine during the substitution reaction was eliminated by the reaction of $\mathrm{CaCO}_{3}$ to $\mathrm{CaCl}_{2}$, because alkaline solutions in general affect the stability of OT. The actual specific activity of synthesized OT was $19 \mathrm{Ci} / \mathrm{mM}$, while the theoretical was $58 \mathrm{Ci} / \mathrm{mM}$. This discrepancy may be due to the interchange of some ${ }^{3} \mathrm{H}$ gas with hydrogen in the water; in fact, it is estimated that $50 \mathrm{Ci}$ of ${ }^{3} \mathrm{H}$ gas has been bound to $\mathrm{H}_{2} \mathrm{O}$ (about $1.25 \mathrm{Ci} / \mathrm{ml}$ ), but as the interchange between ${ }^{3} \mathrm{H}$ and halogen is more rapid than that between ${ }^{3} \mathrm{H}$ and hydrogen, the relatively high specific activity of ${ }^{3} \mathrm{H}$-OT has been obtained.

Using this newly synthesized ${ }^{3} \mathrm{H}-\mathrm{OT}$, several investigations were performed on human myometrial specimens. The \% uptake of ${ }^{3} \mathrm{H}-\mathrm{OT}$ in the $20,000 \times g$ fraction of the human myometrium was maximal

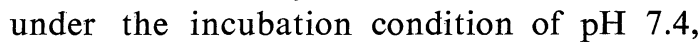
$20^{\circ} \mathrm{C}$ for $90 \mathrm{~min}$, also the uptake was augmented by the presence of $\mathrm{Mn}^{++}$. The ${ }^{3} \mathrm{H}-$ OT binding site, namely the OT receptor activity, was predominantly found in 20,000 $\times g$ particulate and was of a single type within the range of OT concentrations of $0.4 \mathrm{nM}$ to $1.6 \mathrm{nM}$. The binding affinity of OT to OT receptors showed a comparative increase as gestation advanced and so did the NBS value, suggesting that the pregnancy related to the change of the uterine sensitivity to OT may be due to the changes in the receptor or an increase in number of the receptors. In experiments on rats, it was explained that the increased OT receptor affinity together with the increase of NBS during pregnancy might be induced by estrogen (Soloff et al., 1975). In the present study, the NBS value of term pregnancies without labor pain was considerably higher than those in labor, while the Kds did not show any detectable change. This suggests that the OT receptors in the myometrium in the contractile stage may have been saturated with endogenous OT or OT to OT-receptor complex may exert some inhibitory effects on the subsequent binding. The precise mechanism in human uterine tissue, however, still remains to be clarified by the future investigations. We are in the process of setting up a protocol to examine and evaluate these mechanisms. 


\section{Acknowledgement}

We wish to express our sincerest gratitude to Drs. M. Takagi, Y. Ono and K. Hata of SINLOIHI Co. for their excellent procedures of oxytocin tritiation and Dr. K. T. Fujii for his advice and interest in this experiment. This work was supported in part by a research grant from the Ministry of Health and Welfare of Japan for Research on Handicapped Children.

\section{References}

Agishi, Y. and J. F. Dingman (1965). Biochem. Res. Commun. 18, 92.

Chard, T., C. M. Hudson, C. R. W. Edwards and N. R. H. Boyd (1971). Nature 234, 352.

Dawood, M. Y., K. S. Ragharean, C. Pociask and F. Fuchs (1978). Obstet. Gynecol. 51, 138.
Glover, J. S., D. N. Salter and B. P. Shepherd (1967). Biochem. J. 103, 120.

Hata, K., M. Takagi, Y. Ono, Y. Shinozaki, T. Yamamoto and M. Ikeda (1977). Radioisotopes 26, 327 (In Japanese).

Kumaresan, P., P. B. Anandarangam, W. Dianzon and A. Vasicka (1974). Am. J. Obstet. Gynecol. $119,215$.

Lowry, O. H., N. J. Roserough, A. L. Farr and R. J. Randall (1951). J. Biochem. 193, 265.

Morgat, J. L., L. T. Hung, R. Cardinaud, P. Formageot, J. Bockaert, M. Imbert and F. Morel (1970). J. Labelled Compd. 6, 276.

Nunez, J., C. Jacquemin and J. Roche (1962). Int. J. Appl. Radiat. Isot. 13, 593.

Scatchard, G. (1949). Ann. N. Y. Acad. Sci. 51, 660. Soloff, M. S., T. L. Swartz and A. H. Steinberg (1974). J. Clin. Endocrinol. Metab. 38, 1052.

Soloff, M. S. (1975). Biochem. Biophys. Res. Commun. 65, 205.

Thompson, E. E., P. Freychet and J. Roth (1972). Endocrinology 91, 1199. 